\title{
Dynamical Modeling of the Onset of War
}


This page is intentionally left blank 


\section{Dynamical Modeling \\ of the Onset of War}

\section{Alvin M Sapersteln}

Wayne State University, Detroit, Michigan, USA 


\section{Published by}

World Scientific Publishing Co. Pte. Ltd.

P O Box 128, Farrer Road, Singapore 912805

USA office: Suite 1B, 1060 Main Street, River Edge, NJ 07661

UK office: 57 Shelton Street, Covent Garden, London WC2H 9HE

\section{British Library Cataloguing-in-Publication Data}

A catalogue record for this book is available from the British Library.

\section{DYNAMICAL MODELING OF THE ONSET OF WAR}

Copyright $\odot 1999$ by World Scientific Publishing Co. Pte. Ltd.

All rights reserved. This book, or parts thereof, may not be reproduced in any form or by any means, electronic or mechanical, including photocopying, recording or any information storage and retrieval system now known or to be invented, without written permission from the Publisher.

For photocopying of material in this volume, please pay a copying fee through the Copyright Clearance Center, Inc., 222 Rosewood Drive, Danvers, MA 01923, USA. In this case permission to photocopy is not required from the publisher.

ISBN 981-02-4064-3 


\section{PREFACE}

Nations have been making war upon each other throughout recorded history. Many people have been attracted by war's glory and gore; many others have been repelled by it. There have always been those who have attempted to "understand" war's origins and practice. Some wish to satisfy their intellectual curiosity about war and human conflict. Others have hoped to help frame policy so as to control war - to avoid it when possible, to win it or to minimize losses when desired or necessary. Consequently, the written record contains much descriptive and analytical discussion of the origins of war.

There have been two devastating "conventional" world wars in this century. The international system of nominally independent, competing nation states, which gave rise to these (and past) wars, just barely survived the vast "exchanges" of conventional high explosives. The possibility of a nuclear war increases the scale of explosive exchange by factors of millions; the intensity of their use (the rate at which explosives are detonated over civilians and combatants) rises by still further millions. The concomitant major global environmental changes raises the prospect that the outbreak of another major war may destroy the international system itself! Rather than simply modifying the strengths, numbers, and/or the identities of the actors which make up the system, as was the case in the past, a global nuclear war may eliminate the very system of nations which undergirds the possibility of war.

Thus curiosity about the forces leading to war, and the need to frame practical policy to survive as a nationby avoiding such a war, were intensified in the postWorld War II period. Discussion of the topic of war initiation has become much more prevalent among the intellectual and political classes - those who have always been concerned with such issues. In addition, new groups, not previously heard on the subject, have registered their compelling interest in the question of the onset of war. There has been a significant display of concern with the issue from the general publics - the potential "victim classes" of a nuclear holocaust.

Much of this discussion on the onset of war has been traditional in form. There have been extensive verbal descriptions of "what" happened and verbal analysis of "how" and "why". No serious contention has been raised, nor will it be in this book, that this conventional approach is not valid or not useful. However, an alternative - mathematical - approach has been suggested by a number of scholars in the post-WW II era. Some examples of such a mathematical political science of international security and war's onset are developed in this book. The possibilities of applying qualitative and quantitative mathematical reasoning to the problem of international security and the origins of war are endless - perhaps as diverse as the variety of verbal analysis and description historically and commonly employed. The specific goal of this book is to develop the idea of "chaos" in a deterministic international system, and to apply it to simple mathematical models of the interactions between competing states in such a system. It is hoped to use the resultsof such model analysis, via an analogy between such "chaos" and the 
political notion of "crisis instability", in the framing of effective national security policies.

I emphasize that the methods and results obtained in this book are to be viewed as complementary to the usual approaches of verbal political analysis. If the results concur with those obtained in the usual fashion, it is presumed that our belief in these results is strengthened: understanding is enhanced, both theoretical approaches have increased validity, and policy based upon the results will be more likely to prove useful. If the two different approaches - verbal and mathematical lead to discordant results, much more thought and development is required - by each. The fault may lie in the specific models used for analysis in each approach, the general typeology of model, or the basic approach itself. One great advantage of the mathematical approach advocated here, in contrast to the conventional verbal paradigms, is the explicitness of the assumptions made and the manipulations of these assumptions to produce conclusions. It is much easier to try new approaches and ascertain where they might have gone wrong.

Much of this book is based upon a research program which I initiated some fifteen years ago. It has been carried out primarily at Wayne State University, where I have been a professor of physics and an active member of its Center for Peace and Conflict Studies. It also included significant extended stays at the Stockholm International Peace Research Institute (SIPRI), the London International Institute of Strategic Studies (IISS), the Peace Research Institute of Oslo (PRIO), and the U.S. Arms Control and Disarmament Agency (ACDA). I am very grateful to my colleagues at each of these institutions. The program has resulted in a number of publications, many of which are mentioned in the reference sections of the following chapters. Chapter Five is largely based upon my paper "Chaos as a Tool for Exploring Questions of International Security" which appeared in Conflict Management and Peace Science. I am indebted to its editor, Stuart Bremer, for his encouragement of the original paper as well as his permission to use the paper in this book. For similar reasons, I am appreciative of Ray Dacey, who edited the special issue of Synthese, in which my paper "Mathematical Modeling of the Effects of 'Capability' and 'Intent' on the Stability of a Competitive International System" appeared; much of Chapter Six is taken from this paper, which is used with permission of Kluwer Academic Publishers. Much gratitude is due to the editors of the American Scientist, who helped me develop a "popular" version of my previous "scholarly" work ("War and Chaos", American Scientist, 83, 548-557, 1995). It was this article which attracted the attention of Frank Ling of World Scientific Publishing Co. and ultimately led to this book. I am very grateful to the editors of World Scientific for their encouragement and publishing of this book.

I am also indebted to Prof. Fred Pearson, director of our Center for Peace and Conflict Studies for his continued encouragement of these endeavors of mine which, seemingly, have taken me out of the normal bounds of the research expected of a professor of physics. Finally, I have to express my continuing gratitude, and love, to the one who makes all of my scholarly activity - in fact all of my activity - possible: my friend and wife, Harriet Saperstein. 


\section{CONTENTS}

Preface

Chapter 1 Introduction 1

1. Desired Goals for this Book 1

2. Why Study International Relations Scientifically? 4

3. Science, Technology, and Policy Making 8

4. Why Study Mathematical Dynamical Modeling? 10

5. Mathematical Methods of Getting from Now to Then:

$\begin{array}{lr}\text { Dynamic and Stochastic Rules } & 12\end{array}$

6. Testing the Scientific Theory 17

7. How Many Variables are Needed to Describe the $\begin{array}{ll}\text { International System } & 19\end{array}$

8. Complexity - Unexpected Emergence of New Structures 24

9. History 31

10. References and Additional Readings 33

Chapter 2 Predictive Structure Building - Static and Dynamic

1. Static vs Dynamic Modeling in International Aggregation Studies $\quad 35$

2. A Static Model of Aggregation 37

3. A Dynamic Theory of Aggregation 43

4. References and Additional Readings 47

Chapter 3 Predictive Modeling of Arms Races: Static and Dynamic

1. A Static Model of War Initiaiton 49

2. A Dynamic Model of War Initiation 54

3. Problems of Static and Dynamic Models 60

4. Conclusion 64

5. References and Additional Readings 65

\section{Chapter 4 Dynamical Concepts}

1. Attractors - The Goal of Policy Makers

a. Mathematical Examples - Continuous Laws of Evolution

2. Logistics Model - Discrete Law of Evolution 
3. Chaos 82

a. Example - Cantor Set 82

b. Liapunov Exponents 83

c. Strange Attractors 86

4. Linearity 86

a. Is the Whole Just the Sum of its Parts? 88

b. Proof by Contradiction: Linear Systems do not Bifurcate! $\quad 89$

5. Non-Linearity - Must be Present in the Real World 89

6. Complexity and History 91

7. References and Additional Readings 93

Chapter 5 Chaos and International Stability - Modeling War Initiation

1. Prediction and Policy Making 95

2. Predicting War 98

3. Which is More War Prone - A Bipolar or a Tripolar World? 101

4. Are Democracies More or Less Prone to War? 102

5. Which is More War Prone - A System of Shifting

Alliances or a Collection of Go-it-Alone States? 106

6. Conclusions 110

7. References and Additional Readings 112

Chapter 6 Combined Models: Capabilities and Intentions

1. Capability vs Intent 115

2. Modification of the Richardson Model to Include Inter-nation Intents and Economic Constraints 118

3. Modification of the LMZ Model of Intent Variation to Include Military Capability 120

4. A Simple Model for the Impact of Intent and Military Capability Upon Economic Capability

5. Qualitative Consequences of the Combined Model 125

6. References and Additional Readings 128

Chapter 7 Conclusions. Past and Future Research 129 